\title{
THE GUARANTEE FUND FGAR AS A PUBLIC MECHANISM TO PROMOTE ENTREPRENEURSHIP BEYOND THE HYDROCARBON SECTOR \\ KADDOURI Amar ${ }^{\star}$, BOUAZIZ Nawel $^{\star \star}$
}

Received date: $* * / * * / 2017$, Accepted date: $* * / * * / 2017$, online publication date: $* * / * * / 2017$

\begin{abstract}
The promotion of non-hydrocarbon investments remains the main occupation of the Algerian government. The Algerian economy's dependence on hydrocarbons sector remains with $95 \%$ of export earnings, despite all the efforts and attempts token by the Algerian state. Over the last few decades, several measures have been adopted to encourage entrepreneurship and boost investment, by lessening the constraints that face the entrepreneur, in particular, the access of finance. To alleviate this problem, the Algerian government has created, in 20014, the Guarantee Fund for Loans to SMEs (FGAR). It provides guarantees on loans to borrowers by covering a share of the default risk. The aim of this paper is to evaluate the performance of this fund, as a guarantee provider, by analyzing its data and examining its effect on the level of the development of entrepreneurship in Algeria since its creation. The main result is that this guarantee fund has a positive tangible impact on the development of entrepreneurship. Though it has grown in terms of number, entrepreneurship still face various challenges and issues in both enterprise and environment levels that undermine their business conduct. Therefore, much effort is needed in the future to promote and boost the entrepreneurship in order to benefit from all the advantages it gives.
\end{abstract}

Keyword: entrepreneurship, SMEs, FGAR guarantee fund, economic development, finance.

JEL Code: C106

Citation: KADDOURI, A., BOUAZIZ, N. (2017) . The Guarantee Fund FGAR As A Public Mechanism To Promote Entrepreneurship

Ł Kaddouri-exp@yahoo.fr, Dr. KADDOURI Amar: Maître de conference A, High School Of Commerce, Algiers.

$\star \star$ Nawel_bz@hotmail.com, Miss BOUAZIZ Nawel: PhD student, High School Of Commerce, Algiers. 
Beyond The Hydrocarbon Sector. Journal of Finance and Corporate

Governance, Vol., 1, No. 1: pp. 16 - 30. (Jun 2017); ISSN: 2602-5655.

\section{INTRODUCTION}

The concept of entrepreneurship was first established in the 1700s, and the meaning has evolved ever since. Many simply equate it with starting one's own business. Most economists today agree that entrepreneurship is a necessary ingredient for stimulating economic growth and employment opportunities in all societies. In the developing world, successful SMEs are the primary engines of job creation, income growth, and poverty reduction. Therefore, government support for entrepreneurship is a crucial strategy for economic development.

Entrepreneurship has flourished in Algeria. However, for the postindependence period, it can be said that SMEs sector was born late in the 1980s with a mere secondary role played in the local economy prior to that time, whereas its significant expansion has only started in the second half of1990s following incentives and encouragement in favor of the investment promotion made under the new economic. Still, the SMEs in Algeria face many challenges, in particular, the access of finance that represents their main problem. Indeed, financial institutions are usually reluctant to extend uncollateralised credit to SMEs, even at high interest rates in part because of the high costs of obtaining adequate information on the true credit quality. Also, many of these firms do not have the necessary amount and type of assets that could serve as collateral for the loan As a result; many SMEs with economically viable projects cannot obtain the necessary financing from the regular system of financial intermediation.

To alleviate these constraints, the Algerian government has created, in 20014, the Guarantee Fund for Loans to SMEs (FGAR). It provides guarantees on loans to borrowers by covering a share of the default risk of the loan, in case of default by the borrower; the lender recovers the value of the guarantee. In case of a default, the lender usually is obliged to proceed with the collection of the loan and share the proceeds with the guarantor. Credit guarantees allow the partial transfer of credit risk stemming from a loan or a portfolio of loans.

This paper examines the guarantee fund and evaluates its performance to show its contribution, as a guarantee provider and risk taker, to the development of entrepreneurship in Algeria.

\section{LITERATURE REVIEW}

\section{Entrepreneurship in Algeria}

1. Definition of entrepreneurship

Over the last century or so, entrepreneurship has been defined in many different ways. To some economists, the entrepreneur is one who is willing to bear the risk of a new venture if there is a significant chance for profit. Others emphasize the entrepreneur's role as an innovator who markets his innovation. But before providing the definition of the concept entrepreneurship, we should define first who is an entrepreneur? 


\section{a. Entrepreneur}

The term entrepreneur, in French, if literally translated, means "go-between", or "entreprendre," which means "to undertake" and has been used since the 12th Century. During seventeenth century, the term entrepreneur was used for a person who entered into a contractual arrangement with the government to perform a services or supply stipulated products since the contract price was fixed, any resulting profits or losses belonged to the entrepreneurs, thereby assuming the risk arising out of his expedition.

But by the eighteenth a major distinction had been introduced. The industrialization occurring throughout the world, and the inventions developed during this time were reactions to the changing world, leading to differentiate the person with capital from the one who needed capital. In other words, entrepreneur was distinguished from the capital provider. During nineteenth century, entrepreneurs were viewed from an economic perspective. The entrepreneur organizes and operates enterprise for personal gain. He pays current prices for the materials consumed in the business, for the use of land, for personal services he employs and for the capital he requires.

In the 20th century, economist Joseph Schumpeter (1883-1950) focused on how the entrepreneur's drive for innovation and improvement creates upheaval and change. Schumpeter viewed entrepreneurship as a force of "creative destruction." The entrepreneur carries out "new combinations," thereby helping render old industries obsolete.in his words "The function of the entrepreneur is to reform or revolutionize the patter on of production by exploiting an invention or, more generally, an untried technological method of producing a new commodity or producing an old one in a new way, opening a new source of supply of materials or new outlet for products, by organizing a new industry".

In the late 20th century, Business expert Peter Drucker took this idea further differentiating between small business owners and entrepreneurs: "Admittedly, all new small businesses have many factors in common. But to be entrepreneurial, an enterprise has to have special characteristics over and above being new and small. Indeed, entrepreneurs are a minority among new businesses. They create something new, something different; they change or transmute values."

\section{b. Entrepreneurship}

Writing in their report "Entrepreneurship in American Higher Education," the Kauffman Panel on Entrepreneurship Curriculum in Higher Education defined entrepreneurship as "the transformation of an innovation into a sustainable enterprise that generates value...entrepreneurship merges the visionary and the pragmatic". Also, the Babson College defines the entrepreneurship as "a way of thinking and acting that is opportunity obsessed, holistic in approach, and leadership balanced." These two definitions focus on the education of entrepreneurship, the skills, knowledge and process of innovation and new venture creation.

For the National Association for Community College Entrepreneurship's definition," entrepreneurship involves consistently thinking and acting in ways 
designed to uncover new opportunities that are then applied to provide value, while an entrepreneur is an individual that develops a new or improved product, service or way of doing things that can exist independent of the creator, and bears the financial responsibility for risks in bringing their development to market".

According to the Business Dictionary the "entrepreneurship" refers to "The capacity and willingness to develop organize and manage a business venture along with any of its risks in order to make a profit. The most obvious example of entrepreneurship is the starting of new businesses. In economics, entrepreneurship combined with land, labor, natural resources and capital can produce profit. Entrepreneurial spirit is characterized by innovation and risk-taking, and is an essential part of a nation's ability to succeed in an ever changing and increasingly competitive global marketplace".

\section{Entrepreneurship and Small and Medium Enterprises (SMEs)}

Both entrepreneurship development and SMEs have been globally acknowledged as instruments for achieving economic growth and development as well as employment creation.

The existence of diversity of economic entities requires a classification of these various categories. The distinction of these can be done based on a number of criteria. One of these is business size. Thus, economic units are divided into small, medium and large. This discrimination is performed under separate criteria such as number of employees, turnover, invested capital (equity), installed power, market share, if managed and owned by an independent and personal way, etc. Small and medium-sized entities, based on size, were termed SMEs.

a. What is an SME?

The categorization SME is designed to differentiate businesses with relatively small amounts of capital and/or personnel from larger organizations, particularly in relation to market segmentation, financial assistance or regulatory issues.

The main factors determining whether an enterprise is an SME are:

* Staff headcount;

* Either turnover or balance sheet total.

According to the Act on guidance for the promotion of small and medium enterprises, in December 2001, SMEs are defined regardless of their legal status in terms of providing either goods or services, or both, by determining certain characteristics, as presented in table $n^{\circ} 1$ below:

Table 01: classification of SMEs according to the Algerian low $\mathrm{N}^{\circ} 17-02$ of January, $10^{\text {th }} 2017$.

\begin{tabular}{lllll}
\hline $\begin{array}{l}\text { Company } \\
\text { category }\end{array}$ & $\begin{array}{l}\text { Staff } \\
\text { headcount }\end{array}$ & Turnover & or $\begin{array}{l}\text { Balance } \\
\text { total }\end{array}$ \\
\hline Medium-sized & {$[50-250]$} & $>\quad\left[\begin{array}{l}\text { meet } \\
\text { milliards }]\end{array}\right.$ & millions-4 & $\begin{array}{l}>\text { millions } \\
{[200-1.000]}\end{array}$ \\
\hline
\end{tabular}


Vol. 1, No. 1 (Jun 2017); ISSN: 2602-5655

Small [10-49] [20-400[millions $\quad[10-200[$ millions

Micro $\quad[1-9] \quad<20$ millions 10 millions

Source: low $\mathrm{N}^{\circ} 17-02$ of January, $10^{\text {th }} 2017$.

These ceilings apply to the figures for individual firms only. A firm that is part of a larger group may need to include staff headcount/turnover/balance sheet data from that group too.

b. The Roles of SMEs in Algerian economic development

Overall, the growth of the SME population between 2014 and 2015 is $9.7 \%$ in all legal sectors combined, representing a total net increase of 82,516 SMEs for a total population of 934,569 SMEs in 2015 (Industry and mines ministry, 2016).

Table 02: Reported employment by type of SME, (2012-2015)

\begin{tabular}{|c|c|c|c|c|c|c|c|c|}
\hline \multirow{2}{*}{$\begin{array}{l}\text { Types } \\
\text { SMEs }\end{array}$} & \multicolumn{2}{|c|}{2012} & \multicolumn{2}{|c|}{2013} & \multicolumn{2}{|c|}{2014} & \multicolumn{2}{|c|}{2015} \\
\hline & Number & $(\%)$ & Number & $(\%)$ & Number & $(\%)$ & Number & $(\%)$ \\
\hline Private SMEs & 1.800 .742 & 97,44 & 1.953 .636 & 97,59 & $\begin{array}{l}2.110 .66 \\
5\end{array}$ & 97,84 & 2.327 .293 & 98,16 \\
\hline Public SMEs & 47.375 & 2,56 & 48.256 & 2,41 & 46.567 & 2,16 & 43.727 & 1,84 \\
\hline Total & 1.848.117 & 100 & 2.001.892 & 100 & $\begin{array}{c}2.157 .23 \\
2\end{array}$ & 100 & 2.371.020 & 100 \\
\hline
\end{tabular}

Source: Industry and mines ministry, "Statistical Information Bulletin No. 28", May 2016, p. 10.

The data in Table 2 clearly shows that private SMEs appear to be more jobcreating compared to public SMEs in the period 2012-2015. On the other hand, there is a gradual increase in the number of jobs of SMEs from 2012 to 2015, rising from $1,848,117$ jobs to 2,371,020 jobs, i.e. an additional 522,903 jobs.

In general, SMEs plays an influential role in the economic growth and standard of living of the country:

\section{Wealth Creation and Sharing}

By establishing the business entity, SMEs invest their own resources and attract capital (in the form of debt, equity, etc.) from investors, lenders and the public. This mobilizes public wealth and allows people to benefit from the success of entrepreneurs and growing businesses. This kind of pooled capital that results in wealth creation and distribution is one of the basic imperatives and goals of economic development. 


\section{Create Jobs}

SMEs are by nature job creators, as opposed to job seekers. This kind of job creation by new and existing businesses is again is one of the basic goals of economic development.

\section{Balanced Regional Development}

SMEs setting up new businesses and industrial units help with regional development by locating in less developed and backward areas. The growth of industries and business in these areas leads to infrastructure improvements like better roads and rail links, airports, stable electricity and water supply, schools, hospitals, shopping malls and other public and private services that would not otherwise be available.

\section{Standard of Living}

Increase in the standard of living of people in a community is yet another key goal of economic development. SMEs again play a key role in increasing the standard of living in a community. They do this not just by creating jobs, but also by developing and adopting innovations that lead to improvements in the quality of life of their employees, customers, and other stakeholders in the community. For example, automation that reduces production costs and enables faster production will make a business unit more productive, while also providing its customers with the same goods at lower prices.

\section{Exports}

Any growing business will eventually want to get started with exports to expand their business to foreign markets. This is an important ingredient of economic development since it provides access to bigger markets, and leads to currency inflows and access to the latest cutting-edge technologies and processes being used in more developed foreign markets. Another key benefit is that this expansion that leads to more stable business revenue during economic downturns in the local economy.

\section{Community Development}

Economic development doesn't always translate into community development. Community development requires infrastructure for education and training, healthcare, and other public services. For example, you need highly educated and skilled workers in a community to attract new businesses. If there are educational institutions, technical training schools and internship opportunities, that will help build the pool of educated and skilled workers.

\section{c. Evolution and Characteristics of Algerian SMEs}

At the end of 2015, the population of SMEs stood at 934,569 entities (Table $\mathrm{n}^{\circ} 2$ ), of which $58 \%$ are legal entities, of which there are 532 public economic enterprises (EPE). The remainder is composed of natural persons $(42.39 \%)$, of which $19 \%$ are self-employed and $23 \%$ are crafts. 
Table 03: Overall population of SMEs/end of 2015

\begin{tabular}{llcc}
\hline & Type of SME & Number of SMEs & Share \% \\
\hline 1. & Private SMEs & $\mathbf{9 3 4 . 0 3 7}$ & $\mathbf{9 9 , 0 4}$ \\
& Legal entities & 537.901 & 57,56 \\
& Physical persons & 396.136 & 42,39 \\
& Public SMEs & $\mathbf{5 3 2}$ & $\mathbf{0 , 0 6}$ \\
& TOTAL & $\mathbf{9 3 4 . 5 6 9}$ & $\mathbf{1 0 0}$ \\
\hline
\end{tabular}

Source: Industry and mines ministry, "Statistical Information Bulletin No. 28", May 2016, p. 10.

The fabric of the Algerian SME is constituted in its majority of very small size (TPE), with $97 \%$ of the whole population (Table $\left.{ }^{\circ} 4\right)$.

Table 04: typology of SMEs/end of 2015

\begin{tabular}{lcc}
\hline Type of SMEs & Number of SMEs & $\%$ \\
\hline Very Small Business & 907659 & 97,12 \\
Small Business & 24054 & 2,57 \\
Medium Enterprise & 2855 & 0,31 \\
\multicolumn{1}{c}{ Total } & $\mathbf{9 3 4 5 6 9}$ & $\mathbf{1 0 0}$ \\
\hline
\end{tabular}

Source: Industry and mines ministry, "Statistical Information Bulletin No. 28", May 2016, p.11

From the table $\mathrm{n}^{\circ} 03$ and 04, we may conclude that the characteristics of Algerian SMEs exhibit the following specific characteristics that distinguish them from large firms:

\section{$>$ Algerian SMEs are dominated by private enterprises:}

The Algerian SME sector is dominated by private enterprises. According to the Algerian Ministry of Industry, SME and Investment Promotion. By the end of 2015, 99.04\% of all SMEs were private. These percentages indicate that job and wealth creation in the Algerian SME sector are based on-and rely on-private SMEs.

\section{Algerian SMEs are dominated by micro-enterprise types:}

The SME sector in Algeria is dominated by micro-sized enterprises. According to the table $n^{\circ} 04$, at the end of $2015,97.12 \%$ of all SMEs were micro enterprises that employ nine or fewer individuals. The remaining $2.88 \%$ were small and medium enterprises. These statistics indicate that the Algerian economy is based on the fabric 
of micro enterprises in terms of number and relies on such enterprises to absorb unemployment on the one hand and to create wealth on the other hand.

\section{Algerian SMEs are concentrated in north Algeria:}

In Algeria, a disparity exists in the spatial distribution of SMEs, with a higher concentration recorded in the north, followed by the highlands, and finally the greater south.

\section{$>$ Algerian SMEs are concentrated in the service and construction sectors:}

Algerian SMEs have a strong presence in the service sector (particularly transport) and account for nearly half of all SMEs, followed by the building, construction, and hydraulic sector at $33.85 \%$ SMEs (building in particular). The manufacturing sector comprises $16.07 \%$ of all SMEs, and the agriculture and energy sectors account for only $1.09 \%$ and $0.49 \%$, respectively, of total SME activity.

\section{Constraints facing entrepreneurship and the intervention of public sector 1. Constraints facing entrepreneurship}

SMEs in Algeria face several challenges that could hamper their development and affect their ability to create more jobs. These challenges are summarized in table $\mathrm{n}^{\circ} 05$, below:

Table 5: A Comprehensive view of issues facing SMEs in Algeria.

\begin{tabular}{|c|c|c|c|c|c|}
\hline & Financing & $\begin{array}{l}\text { Managemen } \\
\text { t \& Strategy }\end{array}$ & Human Resources & $\begin{array}{c}\text { Productions \& } \\
\text { Technology }\end{array}$ & $\begin{array}{c}\text { Commercializ } \\
\text { ation \& } \\
\text { Markets }\end{array}$ \\
\hline \multirow[t]{2}{*}{$\begin{array}{l}\text { Macro- } \\
\text { Economic } \\
\text { Context }\end{array}$} & $\begin{array}{l}\text { Inefficient } \\
\text { public banks }\end{array}$ & $\begin{array}{l}\text { Lack of clear } \\
\text { strategy for } \\
\text { the }\end{array}$ & $\begin{array}{l}\text { Absence of } \\
\text { continuing vocational } \\
\text { training }\end{array}$ & $\begin{array}{l}\text { Little or lack of } \\
\text { information }\end{array}$ & Liberalization \\
\hline & $\begin{array}{l}\text { Lack of } \\
\text { Capital Risk } \\
\text { and Leasing } \\
\text { Companies }\end{array}$ & $\begin{array}{l}\text { development } \\
\text { of private } \\
\text { sector }\end{array}$ & $\begin{array}{l}\text { Lack of qualified } \\
\text { human capital } \\
\text { Concentration of } \\
\text { qualified people } \\
\text { within public sector }\end{array}$ & $\begin{array}{l}\text { Weak local } \\
\text { market of } \\
\text { equipments } \\
\text { Lack of strategy } \\
\text { of support for } \\
\text { quality and } \\
\text { innovation }\end{array}$ & $\begin{array}{l}\text { Inadequate } \\
\text { rules and } \\
\text { regulations for } \\
\text { competion }\end{array}$ \\
\hline \multirow{3}{*}{$\begin{array}{c}\text { Intermedia } \\
\text { ry } \\
\text { Institutions } \\
\quad \& \\
\text { Supporting } \\
\text { Services }\end{array}$} & $\begin{array}{l}\text { Limited access } \\
\text { to banks }\end{array}$ & $\begin{array}{l}\text { Inefficient } \\
\text { supporting } \\
\text { services }\end{array}$ & $\begin{array}{l}\text { Lack of qualified } \\
\text { trainers }\end{array}$ & $\begin{array}{l}\text { Supporting } \\
\text { services are less } \\
\text { efficient in } \\
\text { terms of }\end{array}$ & $\begin{array}{l}\text { Absence of } \\
\text { supporting } \\
\text { services }\end{array}$ \\
\hline & $\begin{array}{l}\text { Lack of } \\
\text { Information }\end{array}$ & $\begin{array}{l}\text { Limited } \\
\text { number of } \\
\text { institutions }\end{array}$ & $\begin{array}{l}\text { Weak counselling } \\
\text { services }\end{array}$ & $\begin{array}{l}\text { information, } \\
\text { technical } \\
\text { support, quality }\end{array}$ & $\begin{array}{l}\text { Lack of } \\
\text { information }\end{array}$ \\
\hline & $\begin{array}{l}\text { Lack of banks' } \\
\text { credit services } \\
\text { Absence of } \\
\text { supporting } \\
\text { services }\end{array}$ & $\begin{array}{l}\text { Lack of } \\
\text { information }\end{array}$ & & $\begin{array}{l}\text { management } \\
\text { and } \\
\text { development of } \\
\text { innovation }\end{array}$ & $\begin{array}{l}\text { Absence of } \\
\text { training }\end{array}$ \\
\hline $\begin{array}{l}\text { Professional } \\
\text { Groups, }\end{array}$ & $\begin{array}{l}\text { Lack of } \\
\text { guarantee }\end{array}$ & $\begin{array}{l}\text { Entrepreneur } \\
\text { s are not }\end{array}$ & $\begin{array}{l}\text { Lack of consultation } \\
\text { regarding labor }\end{array}$ & $\begin{array}{l}\text { Shortage in } \\
\text { terms of }\end{array}$ & $\begin{array}{l}\text { Weak } \\
\text { promotion of }\end{array}$ \\
\hline
\end{tabular}


Vol. 1, No. 1 (Jun 2017); ISSN: 2602-5655

\begin{tabular}{|c|c|c|c|c|c|}
\hline $\begin{array}{c}\text { Labor } \\
\text { Unions And } \\
\text { Employers }\end{array}$ & $\begin{array}{l}\text { companies and } \\
\text { mutual caution }\end{array}$ & $\begin{array}{l}\text { properly } \\
\text { represented }\end{array}$ & market. & $\begin{array}{l}\text { technical } \\
\text { exchange and } \\
\text { consultation }\end{array}$ & products \\
\hline Associations & $\begin{array}{l}\text { Lack of } \\
\text { cooperation } \\
\text { with banks }\end{array}$ & $\begin{array}{l}\text { Less } \\
\text { powerful } \\
\text { associations }\end{array}$ & $\begin{array}{l}\text { No cooperation with } \\
\text { training institutions }\end{array}$ & $\begin{array}{l}\text { No cooperation } \\
\text { with supporting } \\
\text { centers }\end{array}$ & $\begin{array}{l}\text { Lack of } \\
\text { information } \\
\text { exchange }\end{array}$ \\
\hline \multirow[t]{3}{*}{$\begin{array}{l}\text { Enterprise } \\
\text { Level }\end{array}$} & $\begin{array}{l}\text { Family base } \\
\text { financing }\end{array}$ & $\begin{array}{l}\text { Entrepreneur } \\
\mathrm{s} \text { are } \\
\text { dynamic but }\end{array}$ & $\begin{array}{l}\text { Limited qualification } \\
\text { of technical staffs }\end{array}$ & $\begin{array}{l}\text { Low and } \\
\text { average quality } \\
\text { with high prices }\end{array}$ & $\begin{array}{l}\text { Poor } \\
\text { knowledge } \\
\text { about markets }\end{array}$ \\
\hline & $\begin{array}{l}\text { Traditional } \\
\text { financial } \\
\text { management }\end{array}$ & $\begin{array}{l}\text { they do not } \\
\text { have } \\
\text { strategic } \\
\text { management }\end{array}$ & Staff instability & $\begin{array}{l}\text { Limited } \\
\text { knowhow }\end{array}$ & $\begin{array}{l}\text { Poor channels } \\
\text { of distribution }\end{array}$ \\
\hline & $\begin{array}{l}\text { Lack of } \\
\text { awareness } \\
\text { regarding } \\
\text { banks' } \\
\text { offerings }\end{array}$ & $\begin{array}{l}\text { Weak } \\
\text { innovation } \\
\text { Lack of } \\
\text { information }\end{array}$ & $\begin{array}{l}\text { Entrepreneurs } \\
\text { reluctant to delegate } \\
\text { some authorities to } \\
\text { staff }\end{array}$ & $\begin{array}{l}\text { Poor } \\
\text { organization } \\
\text { Old technology } \\
\text { materials and } \\
\text { equipment }\end{array}$ & $\begin{array}{l}\text { Poor relations } \\
\text { with } \\
\text { customers }\end{array}$ \\
\hline
\end{tabular}

Source: AISSA MOSBAH, development of Algerian SMEs in the age of globalization, Journal of Business and Social Development Volume 2 Number 1, March 2014: P 43

From the table above, we notice that SMEs in Algeria face several constraints, mainly:

- Difficulties to accede financing;

- The Algerian private sector in general and SMEs in particular face cumbersome business environment challenges that affect their development, such as regulatory obstacles, lack of access to industrial real estate, informality, poor quality financial statements, and weak human resource capacities;

- Moreover, these SMEs face several internal challenges that affect their growth and that are a major cause of their failure, such as poor management competences, lack of skilled managers, deficiencies in marketing strategies, weak R\&D and weak technological capacities.

The Algerian government, with the backing of foreign donors, has been making efforts to develop the country's small and medium-sized enterprises (SMEs). There are around 900,000 SMEs and, in October 2015, and the failure rate of companies in the segment had fallen in recent years to around $7-9 \%$ on the back of the government's ongoing efforts.

\section{Access to financing Issue}

In general, and in Algerian economy in particular, the main reasons leading to the access of financing are: 


\section{$>$ Lack of collateral:}

Usable collateral is generally scarce relative to developed economies, and its value is usually more difficult to establish. Also, the range of assets available as collateral is often narrower than in more developed countries, and legal enforcement can be more difficult, both due to limitations in the legal framework.

\section{Reliance on bank lending and lack of alternatives to bank-based intermediation:}

Algeria, as many of the emerging economies, is capital importers, with a substantial part of foreign capital inflows arriving in the form of foreign direct investment or intercompany loans. These forms of financing are not available for SMEs. The information gap between SMEs and the non-resident capital providers are large; the latter lack the local knowledge necessary for funding small companies. Local capital markets and sources of private equity are also often less developed, therefore banks usually represent the only viable source of external financing, even more so than in developed economies.

\section{Less developed networks to obtain credit information:}

SMEs in emerging and transition economies tend to have shorter operational and credit histories. Furthermore, the infrastructure of company information - registrars, credit history databases, rating agencies, etc. - is generally less developed. Ineffective legal systems can also represent additional uncertainty to creditors.

\section{Government Backing}

Since the opening of the Algerian economy in the early 1990s and the progressive adoption of a market economy, a net augmentation in the number of SMEs has been recently recorded. The Algerian government, with the backing of foreign donors, has been making efforts to develop the country's small and medium-sized enterprises (SMEs). There were around 900,000 SMEs and, in October 2015, and the failure rate of companies in the segment had fallen in recent years to around 7-9\% on the back of the government's ongoing efforts.

Algerian authorities have implemented a variety of programs to help eliminating the problems facing the SMEs, such as the National Agency for the Development of SMEs (Agence Nationale de Développment de la PME, ANDPME). As the access to finance has been recognized as a key factor for SMEs to succeed, the strategy set by public authorities to facilitate SMEs financing is based on the provision of guarantee funds, the implementation of financial measures and schemes, and the assistance to the banks willing to fund SMEs. Two guarantee funds were established in favor of SMEs; The Guarantee Fund for Loans to SMEs (FGAR) and the Guarantee Fund for Investment Loans to SMEs (CGCI).

The FGAR which is a national guarantee body for loans to SMEs began operations in 2004 with the aim of facilitating access to medium term bank financing in order to help both start-up and expansion of SMEs. FGAR shares the financing risk of SMEs by covering part of the possible loss incurred by the lending bank. Due to the complexity of the issue, this fund assists SMEs in identifying viable projects. 
In this paper, we will focus on the guarantee fund and evaluate its performance to show its contribution, as a guarantee provider and risk taker, to the development of entrepreneurship in Algeria.

\section{DATA \& METHODOLOGY}

The grantee fund FGAR, as a public mechanism to promote SMEs, provides guarantees on loans to borrowers by covering a share of the default risk. The aim of this paper is to evaluate the performance of this fund, as a guarantee provider, by analyzing its data and examining its effect on the level of the development of entrepreneurship in Algeria since its creation.

\section{Definition of the FGAR}

Credit guarantee fund (FGAR) is a Public Financial Institution, created by Executive Decree $\mathrm{N}^{\circ}$ 02-373 of 11-11-2002 in application of the provisions of article 14 of the law of orientation for the promotion of the SME $n{ }^{\circ}$ 01-18, 12-12-2001. The Fund, with its legal personality and financial autonomy, is under the supervision of the Ministry of Industry and Mines.

It provides guarantees on loans to borrowers by covering a share of the default risk of the loan. In case of default by the borrower, the lender recovers the value of the guarantee. Guarantees are usually provided against a fee, covered either by the borrower, the lender or both. In case of a default, the lender usually is obliged to proceed with the collection of the loan and share the proceeds with the guarantor. Credit guarantees allow the partial transfer of credit risk stemming from a loan or a portfolio of loans. In this respect, they show similarity to credit insurance products and credit default swaps.

\section{The added value of the Fund FGAR}

The fund offers advantages for both SMEs and banks:

\section{$>$ Advantages for SMEs}

It enables SMEs to:

- Access to finance ;

- Have a mediator between the entrepreneur and the bank to improve understanding and communication between the parties;

- Supplement the risk assessment with information on the sector of activity, its economic development, market research, etc.

- Provide financial management advice and support.

\section{$>$ Advantages for banks}

- Share the credit risk ;

- Obtaining a guarantee without additional costs ;

- Reducing the level of demand for collateral ;

- Having an external risk assessment ; 
- reduction of provisions amount;

- Enlarging its clientele.

\section{How does the Fund FGAR work?}

Guarantee schemes vary in terms of the coverage ratio (i.e., the proportion of a loan that is guaranteed), the term, and the way costs and risks are shared among borrower, lender, and guarantor. This fund FGAR distinct between two types of project:

- Creation project : in this project, Guarantee coverage ranges from 10 to 80 percent of the principal amount, without exceeding 100 million DZD depending on the type of borrower or loan product guaranteed;

- Extension project: in this project, the amount could reach 250 million DZD.

This guarantee concerns the investment loans only and does not cover interest payments.

The rate is determined according to a financial and economic study that takes into consideration many criteria such as: the promoter's profile, the nature of product or service to offer, the situation of the market, and the financial viability of the project...

\section{Diagnosis and analysis of FGAR's financial performance}

Since its foundation, FGAR has granted 1,549 guarantees, totaling 42,070 million DZZ, at the end 2015. Of this total of pre-agreements notified, Eight hundred and thirty-four (834) Certificates of Guarantee have been given to the partner banks, representing an overall commitment of 20,190 billion DZA.

FGAR's activity has grown strongly since 2011, but, like other operator in Algerian economy, it was touched but the crisis of price oil that began in 2014, thus, its activity declined in 2015.

- Some statistics on the fund activity,

The following graph highlights the breakdown of commitments by sector of activity

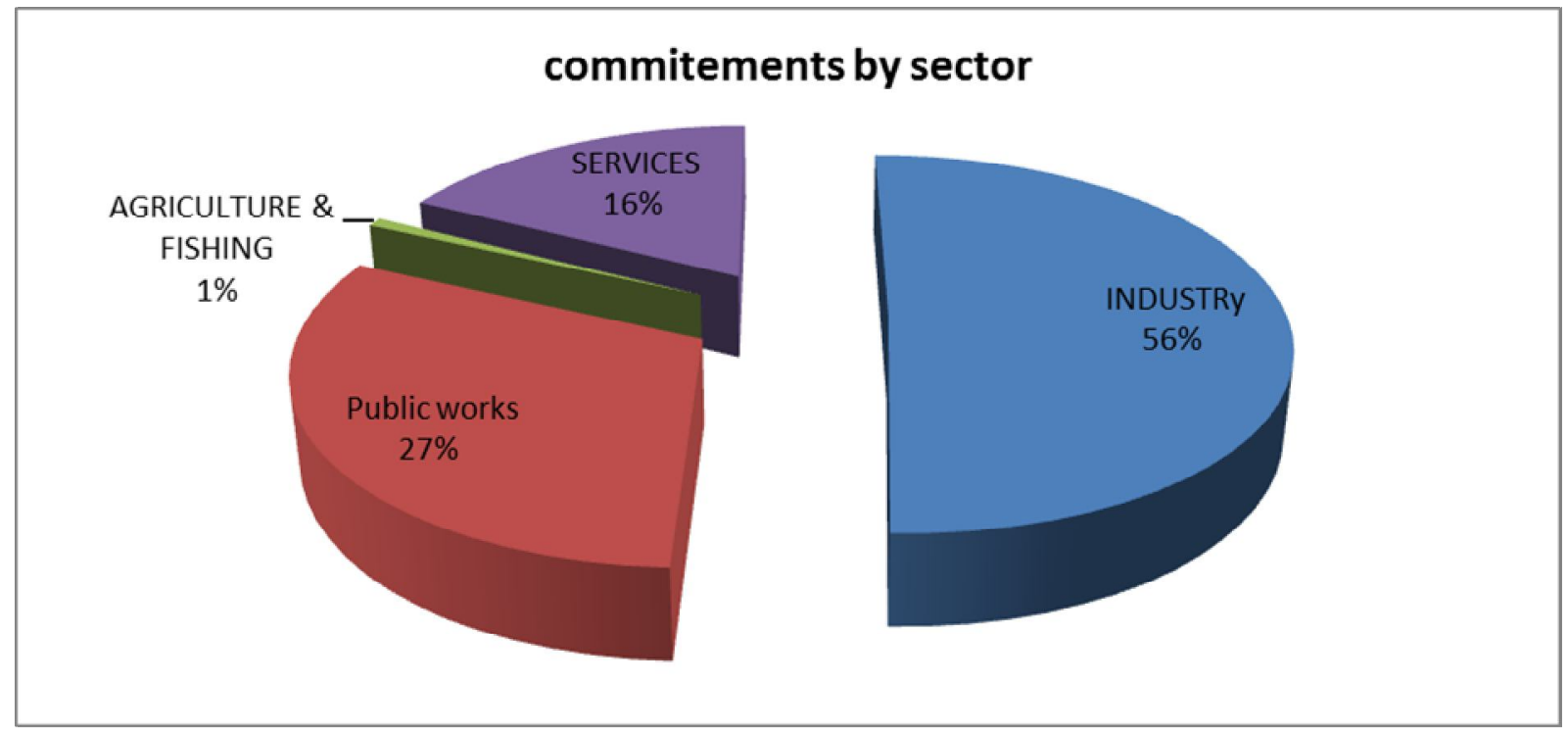

Source: FGAR activity report of 2015

The Fund's commitments are dominated by the industrial sector at $56 \%$, with an average commitment of 40 MDAs per SME, against a $27 \%$ share for public works 
Vol. 1, No. 1 (Jun 2017); ISSN: 2602-5655

with an average commitment of 25 MDA per SME. As for the services sector, it has a $16 \%$ share of commitments.

The following graph shows the distribution of the number of jobs created by sector of activity.

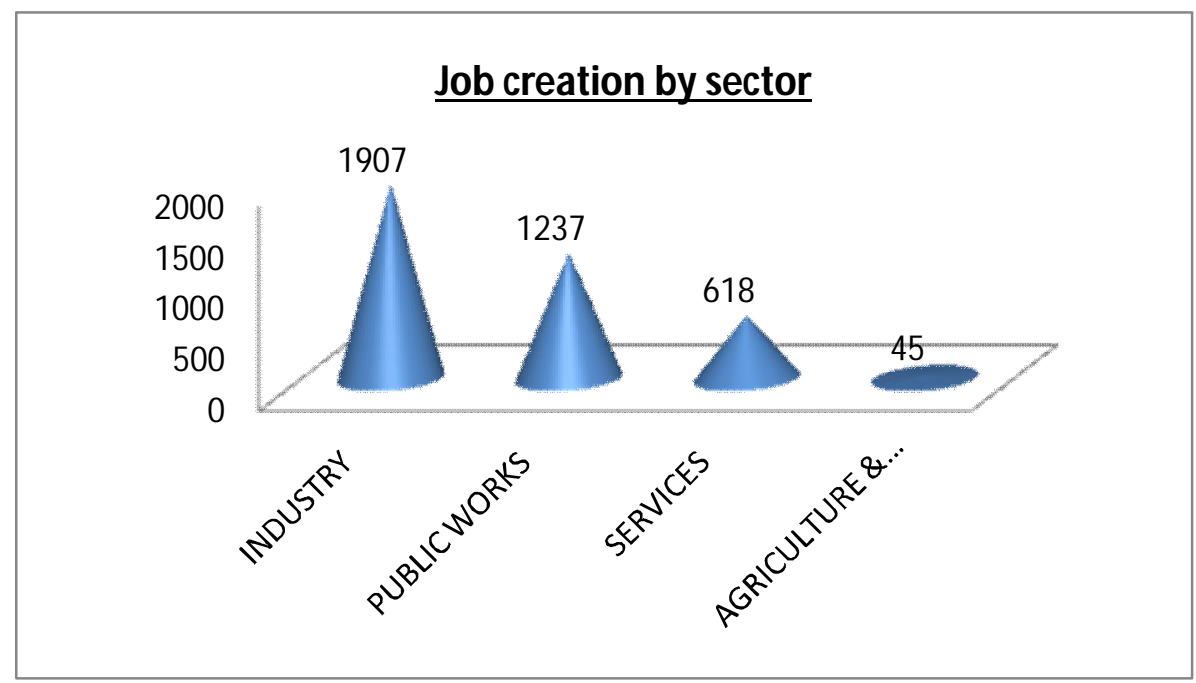

Source: FGAR activity report of 2015

With an average of 20 jobs per project secured, the industry and the public works are the first sectors that create job.

The graph below highlights the weight of the different regions where the fund intervened for the first three quarters of the financial year 2015.

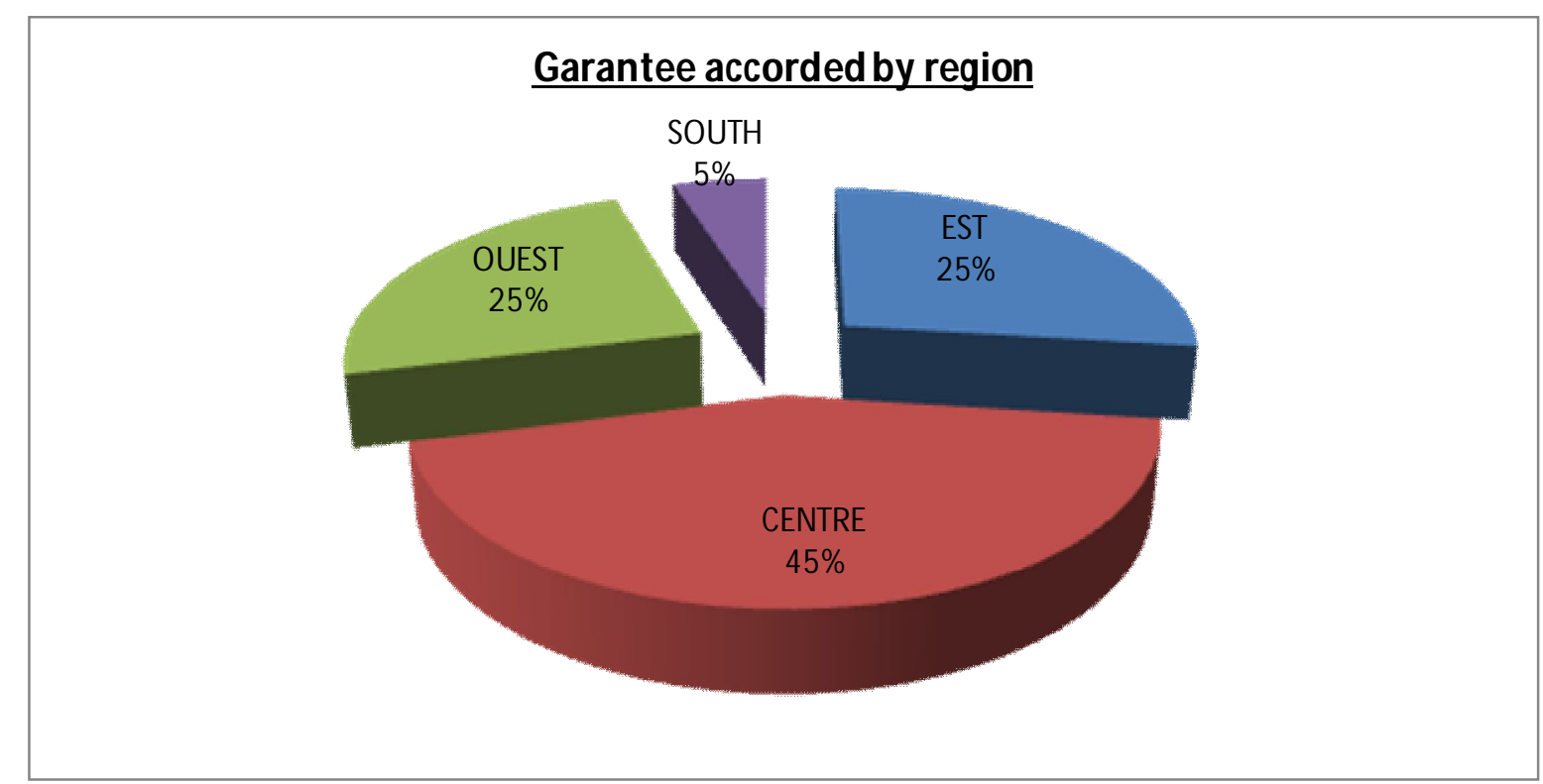

Source: FGAR activity report of 2015 


\section{FINDINGS \& DISCUSSION}

In recent years entrepreneurship has consistently registered higher growth rate compared to the overall industrial sector globally. SMEs, as a major component of entrepreneurship, play an indisputable role, in dynamism and economic development. They represent an essential element for economic integration, diversification, and a means of accelerating the volume of investment, production and a source of job creation. These vulnerable entities represent the core of economic development, and occupy a singular place in the growth of the production apparatus. They constitute a source of wealth, satisfaction of economic and social needs, and absorption of unemployment. But they face a lot of problem mainly the access to finance. As a reaction, the public sector had intervened many programs such the guarantee fund FGAR. As a public institution, financially independent, supervised by the Minister in charge of SMEs, and by providing guarantees on loans (only investment loans are eligible) to borrowers by covering a share of the default risk of the loan, the guarantee fund FGAR had played a major role in the promotion of SMEs situation in Algeria. Indeed, since its creation, close to 1633 guarantees of about 45261 Million DA were provided. The average guarantee size was about 49 percent coverage ratio.

Like we have shown above, the Algerian government has made a great and tangible effort to boost the growth of SMEs through deferent program. However, not all initiatives in the segment have achieved their goals. The IMF has argued that guarantees for SME loans have not helped to significantly improve lending to the sector, and states that SMEs' access to finance is hindered by what it describes as high demand for collateral and difficulties dealing with non-performing loans.

The entrepreneurship in Algeria still face a lot of challenges, and despite of the programs that has been installed by the Algerian government, there are a lot of work to do to promote and boost the entrepreneurship in order to benefit from all the advantages it gives.

\section{REFERENCES}

Anurag Pahuj, Introduction to Entrepreneurship, mars 2015, page 4, PDF https://www.researchgate.net/publication/301659818

The Kauffman Panel on Entrepreneurship Curriculum in Higher Education, Entrepreneurship in American Higher Education," page 8, PDF www.kauffman.org/

NACCE, Defining Entrepreneurship, 2010, page 7, PDF www.nacce.com http://www.businessdictionary.com/definition/entrepreneurship.html. http://www.sciencedirect.com/science/article.

http://ec.europa.eu/growth/smes/business-friendly-environment/sme-definition_fr. Industry and mines ministry, "Statistical Information Bulletin No. 28", May 2016. https://evoma.com/business-centre/7-roles-of-entrepreneurship-in-economicdevelopment-of-a-country/. 
Asma Benzazoua Bouazza, Small And Medium Enterprises As An Effective Sector For Economic Development And Employment Creation In Algeria, International Journal of Economics, Commerce and Management, Vol. III, Issue 2, Feb 2015.

European Investment Bank (EIB). (2011). “Report on Support to SMEs in Developing Countries Through Financial Intermediaries, ”http://www.eib.org/ attachments/dalberg_sme-briefing-paper.pdf

OECD. (2004). Promoting Entrepreneurship and Innovative SMEs in A Global Economy: Towards A More Responsible and Inclusive Globalisation. 2nd OECD Conference of Ministers Responsible for SMEs. 3-5 June, Istanbul

Gharbi. S. (2011). "Current Situation of SMEs in Algeria," (in french), Working Paper $\mathrm{N}^{\circ} 238$, Research Laboratory on Manufacturing and Innovation. Littoral Côte d'Opale University. France, Mars 2011 